\title{
Gudrun.
}

Ins 2Teuhochbeutiche übertragen

volt

\section{Karl Geffel.}

Jweite, vähig umgearbeitete Husgabe.

Bon 1905.

2. Marcus und E. Webers Derlag. 